\title{
Neurofibromatoses: part 1 - diagnosis and differential diagnosis
}

\author{
Das neurofibromatoses: parte 1 - diagnóstico e diagnóstico diferencial \\ Luiz Oswaldo Carneiro Rodrigues ${ }^{1}$, Pollyanna Barros Batista ${ }^{1}$, Eny Maria Goloni-Bertollo², Danielle \\ de Souza-Costa ${ }^{7}$ Lucas Eliam ${ }^{6}$, Miguel Eliam7, Karin Soares Gonçalves Cunha ${ }^{3}$, Luiz Guilherme Darrigo- \\ Junior ${ }^{4}$, José Roberto Lopes Ferraz-Filho ${ }^{2}$, Mauro Geller ${ }^{5}$, Ingrid F. Gianordoli-Nascimento ${ }^{1}$, Luciana \\ Gonçalves Madeira ${ }^{1}$, Leandro Fernandes Malloy-Diniz'. Hérika Martins Mendes ${ }^{1}$, Débora Marques \\ de Miranda ${ }^{1}$, Erika Cristina Pavarino ${ }^{2}$, Luciana Baptista-Pereira ${ }^{1}$, Nilton A. Rezende ${ }^{1}$, Luiza de \\ Oliveira Rodrigues ${ }^{1}$, Carla Menezes da Silva ${ }^{1}$, Juliana Ferreira de Souza ${ }^{1}$, Márcio Leandro Ribeiro de Souza ${ }^{1}$, \\ Aline Stangherlin', Eugênia Ribeiro Valadares ${ }^{1}$, Paula Vieira Teixeira Vidigal ${ }^{1}$
}

\begin{abstract}
Neurofibromatoses (NF) are a group of genetic multiple tumor growing predisposition diseases: neurofibromatosis type 1 (NF1), neurofibromatosis type 2 (NF2) and schwannomatosis (SCH), which have in common the neural origin of tumors and cutaneous signs. They affect nearly 80 thousand of Brazilians. In recent years, the increased scientific knowledge on NF has allowed better clinical management and reduced complication morbidity, resulting in higher quality of life for NF patients. In most cases, neurology, psychiatry, dermatology, clinical geneticists, oncology and internal medicine specialists are able to make the differential diagnosis between NF and other diseases and to identify major NF complications. Nevertheless, due to its great variability in phenotype expression, progressive course, multiple organs involvement and unpredictable natural evolution, NF often requires the support of neurofibromatoses specialists for proper treatment and genetic counseling. This Part 1 offers step-by-step guidelines for NF differential diagnosis. Part 2 will present the NF clinical management.
\end{abstract}

Keywords: neurofibromatoses, neurofibromatosis type 1, neurofibromatosis type 2, schwannomatosis.

\section{RESUMO}

Neurofibromatoses (NF) constituem um grupo de doenças genéticas com predisposição ao crescimento de múltiplos tumores: tipo 1 (NF1), tipo 2 (NF2) e schwannomatose (SCH). Estas doenças têm em comum a origem neural dos tumores e os sinais cutâneos. Afetam cerca de 80 mil brasileiros. O maior conhecimento científico sobre as NF tem permitido melhor manejo clínico, redução da morbidade das complicações e melhor qualidade de vida. Na maioria dos casos, os especialistas em neurologia, dermatologia, genética clínica, oncologia e medicina interna estão capacitados a realizar o diagnóstico diferencial e identificar suas principais complicações. Devido à sua variabilidade fenotípica, curso progressivo, multiplicidade de órgãos acometidos e evolução imprevisível, as NF frequentemente necessitam de especialistas em NF para o acompanhamento. A Parte 1 deste texto oferece orientações para o diagnóstico de cada tipo de NF e discute os diagnósticos diferenciais com outras doenças. A Parte 2 oferecerá orientações em relação ao manejo clínico das NF.

Palavras-chave: neurofibromatoses, neurofibromatose tipo 1, neurofibromatose tipo 2, schwannomatose.

Individuals with neurofibromatoses (NF) usually present to neurologists with one or more of the following clinical findings: cognitive and developmental deficits, macrocephaly, deafness, blindness, neuropathic pain, seizures or benign/ malign tumors of the central nervous system (CNS). Also, NF affected persons may be referred to psychiatrists due

${ }^{1}$ Universidade Federal de Minas Gerais, Belo Horizonte MG, Brazil;

${ }^{2}$ Universidade de São Paulo, Faculdade de Medicina de São José do Rio Preto, Sao Jose do Rio Preto, Brazil;

${ }^{3}$ Universidade Federal Fluminense, Faculdade de Medicina, Niteroi RJ, Brazil;

${ }^{4}$ Universidade de São Paulo, Faculdade de Medicina de Ribeirão Preto, Ribeirão Preto, Brazil;

${ }^{5}$ Universidade Federal do Rio de Janeiro, Faculdade de Medicina, Rio de Janeiro RJ, Brazil;

${ }^{6}$ Radiologia Anchieta, Brasilia DF, Brazil;

${ }^{7}$ Instituto de Neurologia de Goiânia, Goiania GO, Brazil.

Correspondence: Luiz Oswaldo Carneiro Rodrigues; Centro de Referência em Neurofibromatoses, Hospital das Clínicas, Faculdade de Medicina da Universidade Federal de Minas Gerais; Alameda Álvaro Celso, 55; 30150-260 Belo Horizonte MG - Brasil; E-mail: rodrigues.loc@gmail.com

Financial support: CNPq, Capes and Fundação de Amparo à Pesquisa do Estado de Minas Gerais.

Conflict of interest: There is no conflict of interest to declare.

Received 08 November 2013; Received in final form 18 November 2013; Accepted 25 November 2013. 
to behavior disorders, including attention deficit/hyperactivity disorder (ADHD) and autism and/or learning difficulties.

There are three distinct diseases under NF denomination: neurofibromatosis type 1 (NF1), neurofibromatosis type 2 (NF2) and schwannomatosis (SCH). The NF share the genetic autossomal dominant predisposition to multiple tumor growth and the neural origin of tumors and cutaneous signals. They are progressive, present a great heterogeneity in phenotype expression and have unpredictable natural course. The NF differ profoundly in age of first manifestations, symptoms, evolution and prognosis ${ }^{1}$.

NF diseases affect nearly 80 thousands of Brazilian individuals $^{2}$ and if NF is suspected, it is necessary to distinguish NF1 from NF2 and SCH. Figure 1 depicts a stepwise diagnosis pathway to distinguish the three NF diseases. In most cases, the differential diagnosis among the NF diseases is made with certainty. Nevertheless, special NF patients present overlap with some other diseases because of: a) cafe au lait lesions (CAL); b) localized hyper growth syndromes; c) neurofibromas-like tumors; and d) multiple endocrine neoplasia. These particular situations should deserve attention from the NF specialist.

The present Part 1 text offers step-by-step guidelines for differential diagnosis among the neurofibromatosis types and other diseases. A further Part 2 will present the NF clinical management. Basic information for patients can be found in www.amanf.org.br.

\section{STEP BY STEP DIAGNOSIS OF NF1, NF2 AND SCH}

Figure 1 depicts a practical step-by-step guide to differentiate NF1 from NF2 and SCH. The first two questions to be answered are: are there cafe au lait lesions (CAL)? Are there tumors?

\section{STEP 1- ARE THERE CAFÉ AU LAIT LESIONS?}

Yes - CAL are usually multiple and present or develop at birth or in early infancy and are observed in $99 \%$ of people with NF1 by age of 3 years. They are macules with uniform ovoid shape and smooth outline, varying of light to dark brown color (Figure 2A). Its size varies from $5 \mathrm{~mm}$ (infancy) to $30 \mathrm{~mm}$ (adulthood), but they can be bigger than $20 \mathrm{~cm}$ and involve an entire anatomic region ${ }^{4}$. The CAL size is proportionate to body growth and they are randomly distributed, although scalp, palms, and soles are spared $^{5}$. Many

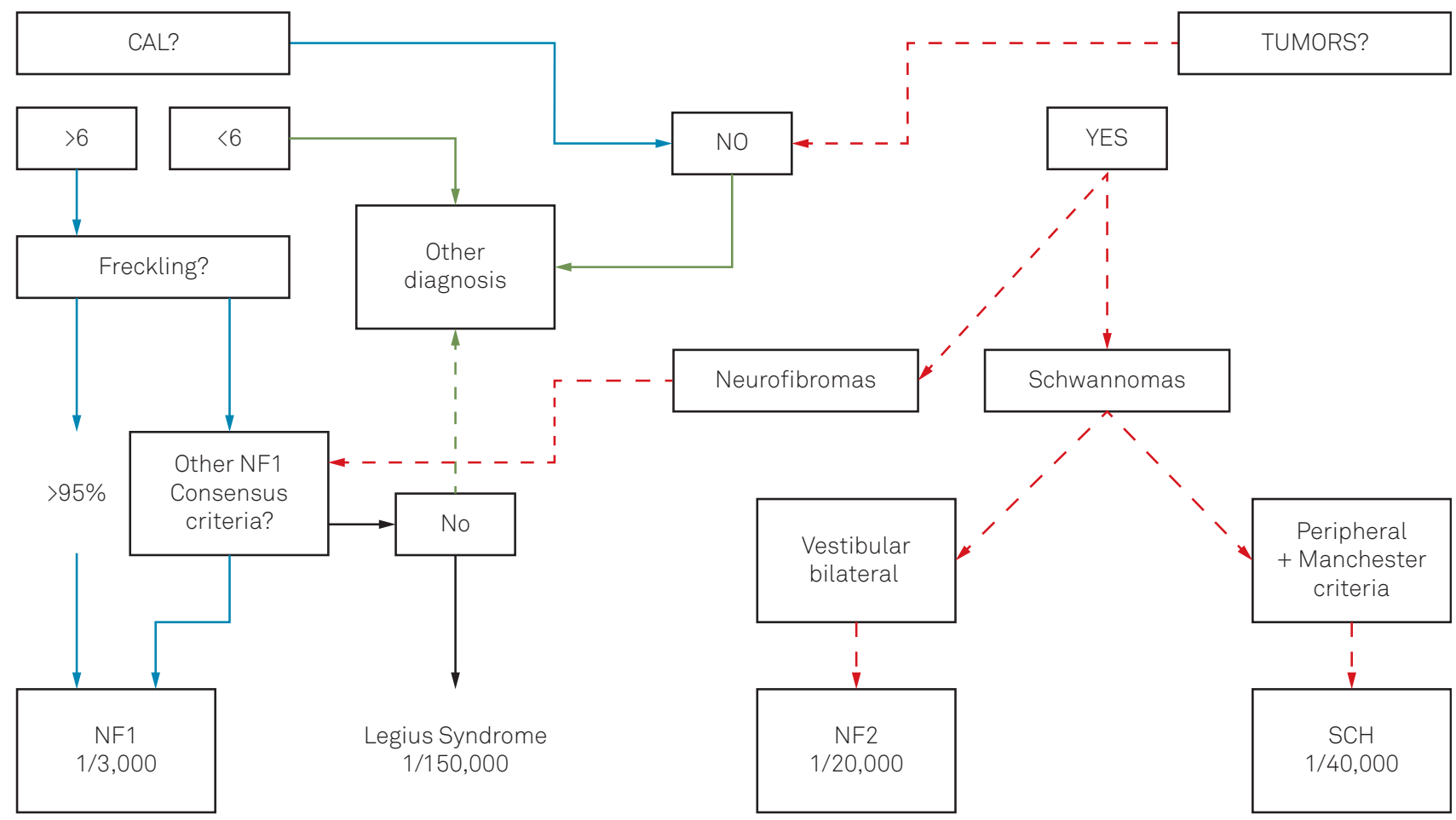

Figure 1. Practical flowchart to differentiate NF diseases: neurofibromatosis type 1 (NF1), type 2 (NF2) and schwannomatosis $(\mathrm{SCH})$. The main questions are: 1) How many cafe au lait lesions (CAL) (Figure 2A) are there? Are there freckling (Figure 2B)? The pathways are shown by blue continuous lines and arrows; 2) Are there tumors: neurofibromas (Figure 2C) or schwannomas? The pathways are shown by red dashed lines and arrows for CAL, freckling and other NF1 criteria (Table 1). Manchester criteria for NF2 and SCH (Table 2), neurofibromas and schwannomas characteristics are described in the text. Main differences between NF1, NF2 and SCH are presented in Table 3. Legius syndrome, special NF1 cases (Table 4) and other diagnoses (green lines) are presented in Table 5. Adapted from Huson et al. ${ }^{3}$. 


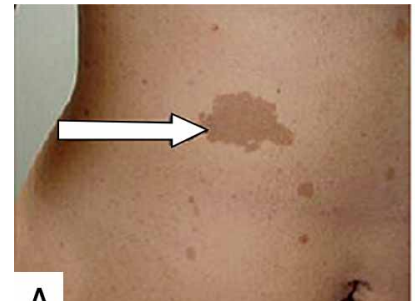

A

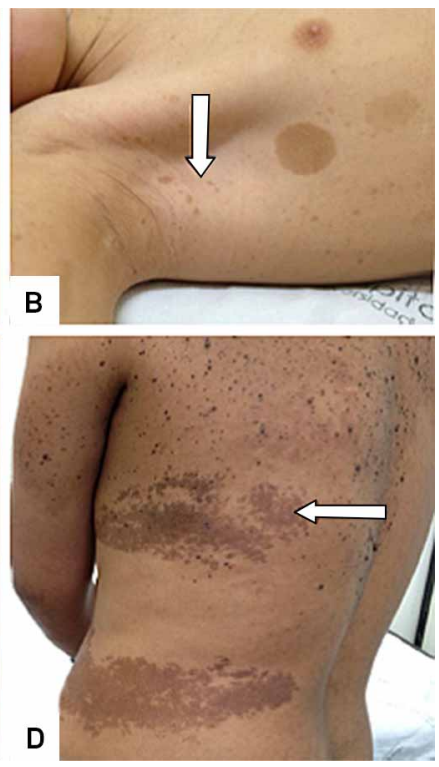

Figure 2. Cutaneous lesions (arrows): Multiple cafe au lait lesions (CAL) (A); freckling and two CAL (B); Discrete neurofibromas (C); Pigmented skin lesions (epidermal nevus) misdiagnosed as CAL and freckling in a non-NF1 patient (D). Pictures made with patient's permission at the Centro de Referência em Neurofibromatoses.

other hyperpigmented skin lesions are commonly misdiagnosed as CAL, such as the lesion in Figure 2D.

Six or more typical CAL are a strong sign (95\%) of NF1. NF1 is the most common condition associated with multiple CAL and patients with a higher number of CAL are more likely to develop NF1, but CAL can also be seen in other syndromes (Table 5). On the other hand, the presence of more than three CAL is detected in only $0.3 \%$ of children with no evidence of genetic disorders ${ }^{6}$.

\section{STEP 2 - ARE THERE AXILLARY AND INGUINAL FRECKLING?}

Yes - Axillary and/or inguinal freckling are hyperpigmented spot macules $(1-3 \mathrm{~mm})$ and the second most common feature in NF1 (Figure 2B). Their appearance is similar to solar-induced freckling, but in NF1 they occur typically in areas with minimal to none sun exposure. Freckling generally appears between 3 and 5 years of age in the axillae and/or inguinal region. Other sites include neck and breasts, around the lips, and even the trunk in adults, but in these sites they are not a diagnostic criterion ${ }^{6}$.

Until recent years, the presence of CAL associated with freckling was enough to the NF1 diagnosis. Nevertheless, the discovery of the Legius syndrome (LEGIUS), which has in common with NF1 the CAL, the freckling, macrocephaly and cognitive deficits, made required a third criterion to make the NF1 diagnosis certain ${ }^{7}$. LEGIUS could be considered the fourth NF disease ${ }^{3}$.

\section{STEP 3 - ARE THERE OTHER NF1 CONSENSUS CRITERIA?}

The diagnostic criteria for NF1 have been established by a National Institute of Health consensus of experts in 1987. A person is thought to have NF1 if they have two or more of the Table 1 criteria.

\section{STEP 4 - ESTABLISHED NF1 DIAGNOSIS (PREVIOUS VON RECKLINGHAUSEN'S DISEASE)}

NF1 is the most prevalent human monogenetic disease (incidence of 1:2,500 live births) $)^{14}$, it is an autossomal dominant disorder caused by hereditary or new mutations in the neurofibromin protein codification gene, located in Chromosome 17 (locus 17q11.2), which results in neural and other tissues dysplasia and increased tumor formation of neural origin ${ }^{15}$.

Table 1. National Institute of Health NIH consensus criteria ${ }^{8}$ and the approximate Brazilian prevalence of the criteria ${ }^{9-11}$, which are similar to international literature, except for tumors (recent review prevalence presented in bold parenthesis ${ }^{12}$ ). The descriptions of cafe au lait (CAL), freckling, neurofibromas, optical glioma (OPG) and osseous dysplasia are presented in the text. Lisch Nodules are harmartomas in the iris, which are specific of Neurofibromatosis (NF1). Many features of NF1 increase in frequency with age. At age 1, only $50 \%$ of patients fulfill the $\mathrm{NIH}$ criteria, but at age 8 , almost all patients have fulfilled the diagnostic criteria $^{13}$

\begin{tabular}{|c|c|c|}
\hline Criteria & Description & Prevalence \\
\hline CAL & $\begin{array}{l}\text { Six or more CAL }>5 \mathrm{~mm} \text { in the larger } \\
\text { diameter in prepubertal individuals } \\
\text { and }>15 \mathrm{~mm} \text { in the larger diameter } \\
\text { in post pubertal individuals }\end{array}$ & $95 \%$ \\
\hline
\end{tabular}

Freckling Two or more freckles in the axillary $87 \%$ or inguinal regions

Neurofibromas

Two or more of any type (cutaneous, subcutaneous, spinal)

Or one plexiform $35 \%(60 \%)$

Glioma

Optical nerve or optical pathway tumor (astrocytoma) diagnosed by nuclear magnetic resonance

Lisch nodules Two or more nodular harmartomas in the iris, diagnosed by the ophthalmologist

Osseous A distinctive osseous lesion such as dysplasia sphenoid dysplasia or thinning of long bone cortex with or without pseudoarthrosis sibling, or offspring) with established NF1 by the above criteria 


\section{STEP 5 - ARE THERE TUMORS?}

Most NF cases are associated with some CAL; therefore, its absence suggests other diseases. Nevertheless, considering that some special NF patients do not have CAL, the next step is to search for tumors.

The common types of tumors associated with NF1 are neurofibromas $(n f b s)$, plexiform neurofibromas (PNF), malignant peripheral nerve sheath tumors (MPNST) and optic glioma (OPG) (see below). The presence of two or more of these tumors is strongly suggestive of NF1 and other $\mathrm{NIH}$ criteria must be investigated (STEP 4). If no other criterion is found, this situation deserves a NF specialist support. On the other side, the presence of two or more schwannoma tumors (see below) is suggestive of both NF2 and $\mathrm{SCH}$.

\section{NF1 ASSOCIATED TUMORS}

Although a specialized physician usually recognizes the different types of neurofibromas, the diagnostic certainty needs further histological studies. Below, we present a brief description of NF1 commonest tumors ${ }^{2,16}$ and detailed histological information can be found elsewhere ${ }^{17}$.

\section{NEUROFIBROMAS (WHO GRADE I)}

Neurofibromas, the hallmark tumors of NF1, are benign tumors of the peripheral nerve sheath. They exhibit extensive cellular heterogeneity (Schwann cells, perineural cells, mast cells, fibroblasts and axons in an extracellular matrix) and it can be classified into two major types: localized and PNF.

Localized neurofibromas are the most prevalent type of tumor in NF1. They tend to develop from skin sensory nerves and usually present as a cutaneous and/or subcutaneous tumor that remains associated with a single nerve ending. The $n f b s$ are more commonly found on the skin, but other sites can also be affected, such as the spinal roots, heart, stomach, larynx, bladder, bowels and oral mucosa.

Plexiform neurofibromas are almost always associated with NF1 and they are classified as benign peripheral nerve sheath tumors that involve multiple nerve fascicles or large branches of a major nerve. PNF are the first and foremost source of morbidity in NF1, due to their tendency to grow to large sizes and their capacity to cause significant deformity and compression of adjacent structures. Some may be present at birth, but most of them usually become apparent during the first two years of life and, if not present by then, rarely develop after adolescence. The growth rate associated with these neoplasms is unpredictable, with periods of rapid growth followed by periods of relative inactivity.

\section{MALIGNANT PERIPHERAL NERVE SHEATH TUMOR (WHO GRADE II, III OR IV)}

MPNST commonly derive from pre-existing PNF. The NF1 patient lifetime risk of developing MPNST is $8-13 \%$ (being the double in the NF1 microdeletion subtype). Because MPNST develop from malignant progression of pre-existing PNF, the risk of developing MPNST increases to almost $50 \%$ in patients with $\mathrm{NF} 1$ and $\mathrm{PNF}^{18}$. MPNST occurrence in childhood and adolescence is uncommon. Incidence is higher among adults in the third to sixth decade of life. MPNST should be suspected when the patient develops persistent pain with no other explanation and/or unexplained neurological deficit associated with changes in texture and enlargement of the PNF. Histological differentiation between a PNF with atypical features and a low grade MPNST is difficult, since these lesions actually represent a histological continuum and it is possible to find lesions with areas of atypical features adjacent to areas of frank MPNST.

\section{GLIOMAS}

Gliomas are the predominant CNS tumor type associated with NF1 and they may occur in all parts of the nervous system, with a preference for the optic pathways, brainstem and cerebellum. Frequent NF1-associated gliomas include optic pathway gliomas (OPG), other pilocytic astrocytomas, diffuse astrocytomas and glioblastomas.

\section{OPG (WHO GRADE 1)}

The majority of OPG in NF1 patients are pilocytic astrocytomas that are located within the optic nerve. Macroscopically most pilocytic astrocytomas are a relatively circumscribed, slowly growing soft-grey mass. Intra or paratumoural cyst formation is common. Optic nerve tumors also often show collar-like involvement of the subarachnoid space. Histopathologically, this astrocytic tumor of low to moderate cellularity exhibits an often biphasic pattern with varying proportions of compacted bipolar cells with Rosenthal fibers and loose-textured multipolar cells with microcysts and granular bodies/hyaline droplets. Rare mitosis, hyperchromatic and pleomorphic nuclei, glomeruloide vascular proliferation, infarct-like necrosis and infiltration of leptomeninges are compatible with the diagnosis of pilocytic astrocytoma and are not signs of malignancy ${ }^{19}$. Bilateral growth, when present, is characteristic of NF1. 


\section{DIFFUSE ASTROCYTOMAS (WHO GRADE II)}

That is a diffusely infiltrating astrocytoma that typically affects young adults and is characterized by a high degree of cellular differentiation and slow growth; the tumor occurs throughout the CNS but is preferentially supratentorial and has an intrinsic tendency for malignant progression to anaplastic astrocytoma and, ultimately, glioblastoma.

\section{GLIOBLASTOMA (WHO GRADE IV)}

The most malignant neoplasm with predominant astrocytic differentiation; histological features include nuclear atypia, pleomorphic cells, mitotic activity, vascular thrombosis, microvascular proliferation and necrosis. It typically affects adults and is preferentially located in the cerebral hemispheres. Most glioblastomas manifest rapidly de novo, without recognizable precursor lesions (primary glioblastoma). Secondary glioblastomas develop slowly from diffuse WHO grade II astrocytoma or anaplastic astrocytoma (WHO grade III). Due to their invasive nature, glioblastomas cannot be completely removed and, despite progress in radio/chemotherapy, less than half of patients survive more than one year, with older age being the most significant adverse prognostic factor.

\section{OTHER NF1 ASSOCIATED TUMORS}

NF1 patients present with a higher risk of developing other tumors such as:

\section{SARCOMAS}

Gastrointestinal stromal tumor (GIST)

\section{NEUROENDOCRINE/NEUROECTODERMAL TUMOURS}

Pheochromocytomas

Carcinoid tumor

Medullar thyroid carcinoma

C-cell hyperplasia

\section{HEMATOPOIETIC TUMORS}

Juvenile chronic myeloid leukemia

Juvenile xanthogranuloma

Acute lymphocytic leukemia

Non Hodgkin lymphoma
STEP 6 - ARE THERE BILATERAL VESTIBULAR

SCHWANNOMAS (BVS)?

Yes - The presence of BVS is a hallmark of NF2. NF2 is an autossomal dominant disorder caused by hereditary or new mutations in the merlin protein codification gene located in chromosome 22 (locus 22q12.2). NF2 presents with BVS, multiple meningiomas, juvenile subcapsular cataract and peripheral schwannomas and other neural tumors.

\section{SCHWANNOMAS (WHO GRADE I)}

Schwannomas are benign true nerve sheath neoplasms composed entirely of Schwann cell proliferation, well circumscribed, nodular or ovoid, usually encapsulated dermal, subcutaneous and central nerves tumors ${ }^{2}$.

The prevalence of NF2 vary from 1:25,000-33,000 individuals ${ }^{20}$ and it presents with deafness and/or tinnitus (50\%), balance dysfunction (5\%), focal weakness or sensory change $(18 \%)$, seizure $(5 \%)$, ocular symptoms $(7 \%)$ and genetic or radiographic diagnosis of an asymptomatic family member (10\%), during the second decade or early adulthood ${ }^{21}$.

Nevertheless, some special cases of NF2 are less evident. The Manchester (modified NIH) diagnostic criteria for NF2 have been expanded to include patients with no family history who have multiple schwannomas and or meningiomas, but who have not yet developed bilateral vestibular nerve tumors $^{22}$. The diagnosis is best confirmed using high quality MRI of the brain.

If there are two or more painful schwannomas, the present step is to complete the diagnosis of $\mathrm{SCH}$ with the following criteria $^{23}$. Table 2 presents the consensus criteria for $\mathrm{NF} 2$ and $\mathrm{SCH}$ diagnosis.

$\mathrm{SCH}$ typically becomes symptomatic during the third decade of life and presents a prevalence of 1:40,000 individuals. The molecular biology of SCH has not been well established yet and a candidate gene for $\mathrm{SCH}$, called INIl, was identified, but the NF2 gene and possibly other genes may also be involved. Unlike NF1 and NF2, SCH does not have a clear pattern of inheritance.

The Table 3 summarizes the main clinical differential characteristics of NF1, NF2 and $\mathrm{SCH}$.

\section{NF1 VARIATIONS}

There are genetically related (allelic) disorders, where apparently pathogenic NF1 mutations have been demonstrated in a few individuals or families who do not have NF1 according to the NIH Diagnostic Criteria ${ }^{4}$. They have specific phenotype and clinical course and are presented in Table 4 and its management will be discussed in Part 2 of this text. 


\section{NF2}

Confirmed

diagnosis

Bilateral masses of the vestibular (eighth cranial nerve) seen with appropriate imaging techniques (e.g., CT or MRI) plus family history of NF2 or unilateral vestibular schwannoma plus any two of the following: neurofibroma, meningioma, glioma, schwannoma, juvenile posterior subcapsular lenticular opacity.

Probable diagnosis Multiple meningiomas (two or more) plus unilateral vestibular schwannoma or any two of the following: neurofibroma, glioma, schwannoma and cataract.

\begin{tabular}{ll}
\hline SCH \\
$\begin{array}{l}\text { Confirmed } \\
\text { diagnosis }\end{array}$ & $\begin{array}{l}\text { Age over } 30 \text { years and two or more schwannomas (at least one with histological confirmation) and no evidence of a } \\
8^{\text {th }} \text { nerve tumor on high-quality MRI scan and no known constitutional NF2 mutation or one pathologically confirmed } \\
\text { non-vestibular schwannoma plus a first-degree relative who meets the above criteria. }\end{array}$ \\
$\begin{array}{l}\text { Presumed } \\
\text { diagnosis }\end{array}$ & $\begin{array}{l}\text { Age under } 30 \text { years and two or more schwannomas (at least one with histological confirmation) and no evidence of } \\
\text { a } 8^{\text {th }} \text { tumor on high-quality MRI scan and no known constitutional NF2 mutation or age over } 45 \text { years and two or more } \\
\text { non-intradermal schwannomas, at least one with histological confirmation and no symptoms of } 8^{\text {th }} \text { nerve dysfunction } \\
\text { and no known constitutional NF2 mutation OR radiographic evidence (images scans) of a non-vestibular schwannoma } \\
\text { plus a first-degree relative meeting the criteria for definite schwannomatosis. }\end{array}$ \\
\end{tabular}

\section{MOSAICISM OR SEGMENTAL NF}

Occasionally NF1, NF2 (rarely) and schwannomatosis (often) occur in mosaic forms. Mosaicism in NF1 is observed more frequently and results from somatic mutations. Early somatic mutations cause generalized disease, clinically indistinguishable from no mosaic forms. Later somatic mutation gives rise to localized disease often described as segmental. In individuals with mosaic or localized manifestations of NF1 (segmental NF1), disease features are limited to

Table 3. Clinical differential characteristics of neurofibromatosis (NF1, NF2) and schwannomatosis (SCH).

\begin{tabular}{|c|c|c|c|}
\hline Features & NF1 & NF2 & $\mathrm{SCH}$ \\
\hline First signs and symptoms & Infancy & Beginning of adulthood & Adulthood $>30$ years \\
\hline Typical findings & Multiple CAL and neurofibromas & Deafness and balance dysfunction & Pain \\
\hline Ocular findings & Lisch Nodules & Juvenile posterior subcapsular cataract & None \\
\hline Growth & $\begin{array}{l}\text { Macrocephaly, short stature, } \\
\text { cognitive deficits }\end{array}$ & Normal & Normal \\
\hline \multirow[t]{2}{*}{ Tumors } & $\begin{array}{l}\text { Neurofibromas: (cutaneous, plexiform } \\
\text { and intraneural - } 60 \% \text { ) }\end{array}$ & $\begin{array}{c}\text { Schwannomas: bilateral vestibular } \\
\text { (>95\%), other cranial (24-51\%), } \\
\text { cutaneous }(59-68 \%) \text {, peripheral } \\
\text { nerve }(42 \%)\end{array}$ & $\begin{array}{l}\text { Schwannomas: } \\
\text { peripheral and painful }\end{array}$ \\
\hline & $\begin{array}{l}\text { Gliomas: benign (optic pathways } \\
\text { 15-20\%) and malignant }(0,8 \%) \\
\text { Pheochromocytomas }(0,1-13 \%)\end{array}$ & $\begin{array}{c}\text { Meningiomas: intracranial (50\%) } \\
\text { Ependymomas (33-53\%) } \\
\text { Mesothelioma }\end{array}$ & \\
\hline Prevalence & $1: 2,500$ a $1: 7,800$ & $1: 20,000$ a $1: 40,000$ & $1: 40,000$ \\
\hline Cancer risk & $\begin{array}{c}\text { Increased: MPNST (8-13\%); GIST } \\
\text { (5-30\%), leukemia (1\%), } \\
\text { rhabdomyosarcomas (1-6\%), breast } \\
\text { cancer } 8,4 \%)\end{array}$ & Habitual & $?$ \\
\hline Osseous problems & Dysplasias & None & None \\
\hline Inheritance & $\begin{array}{l}\text { Autossomal dominant with } \\
\text { complete penetrance }\end{array}$ & $\begin{array}{l}\text { Autossomal dominant with variable } \\
\text { penetrance }\end{array}$ & Not well understood \\
\hline Gene & Chromosome 17 (locus 17q11.2) & Chromosome 22 (locus 22q12.2) & $\begin{array}{l}\text { Chromosome } 22 \\
\text { (locus 22q12.2) }+ \\
\text { SMARCB1 (or INI1)? }\end{array}$ \\
\hline
\end{tabular}

CAL: cafe au lait lesions; MPNST: malignant peripheral nerve sheath tumor; GIST: gastrointestinal stromal tumor; prevalence of tumors ${ }^{12}$. 
Table 4. Neurofibromatosis (NF1) variations. The four identified NF1 subtypes with its main clinical characteristics ${ }^{4}$.

$\begin{array}{lc}\text { Subtype } & \text { Main characteristics } \\ \begin{array}{l}\text { Watson } \\ \text { syndrome }\end{array} & \text { CAL, Lisch, freckling, pulmonary stenosis, short stature, macrocephaly, cognitive deficits, neurofibromas. } \\ \begin{array}{l}\text { Gene deletion } \\ (5 \%)\end{array} & \begin{array}{c}\text { NF1 gene large deletions - dysmorphic facial features: hypertelorism, downslanting palpebral fissures, broad fleshy } \\ \text { noses, "coarse" face becoming more marked with age, overgrowth with tall stature and large hands and feet, Pectus } \\ \text { excavatum, broad neck, excess of tissue in hands and feet, joint hyperflexibility, muscular hypotonia, bone cysts, pes } \\ \text { cavus, dermal (cutaneous) neurofibromas occurring at early age and in increased numbers, including spinal } \\ \text { neurofibromas, double lifetime risk of MPNST than NF1 population, significant delay in cognitive development, learning } \\ \text { difficulties, congenital heart disease and scoliosis (Huxon, The Neurofibromatoses: Differential Diagnosis and Rare }\end{array} \\ \text { Subtypes, 2011). }\end{array}$

Mosaicism

Two or more NF1 criteria present only in specific body part (see below).

$(1 \%)$

Spinal form Few CAL, normal or higher stature, few or absent cutaneous neurofibromas, but multiple spinal neurofibromas, usually bilateral and involving all 38 spinal nerve roots. MPNST higher risk.

CAL: cafe au lait; MPNST: malignant peripheral nerve sheat tumor.

the affected area, which varies from a narrow strip to one quadrant and occasionally to one half of the body. Distribution is usually unilateral but can be bilateral, either in a symmetric or asymmetrical arrangement.

\section{DIFFERENTIAL DIAGNOSIS}

The main characteristics of other diseases, which present differential diagnosis with NF1, are summarized in Table 5.

\section{WHEN ORDERING GENETIC TESTS}

Approximately $50 \%$ of individuals with NF1 or NF2 have not inherited the disease from a parent and are result of a de novo mutation. Individuals who meet the clinical diagnosis criteria for NF1, NF2 and SCH are diagnosed with confidence in most cases, and genetic tests are not required for diagnostic confirmation. Therefore, genetic testing may be helpful in specific cases. The decision to order or not a genetic test remains a physician/patient (family) discussion. Genetic testing for NF is clinically available in just a few laboratories around the world. For an updated list of laboratories that offers genetic tests for NF, please refer to www.genetests.org.

\section{NF1 VERSUS LEGIUS SYNDROME}

The NF1 gene is large (280 kb and 60 exons) and most mutations are unique to a particular family, what turns the molecular diagnostic testing laborious and expensive. A definite diagnosis of NF1 can be made in most children by age four using only the NIH criteria ${ }^{24}$. Confirmatory diagnostic testing can detect the mutation in $95 \%$ of cases and is indicated for suspected NF1 individuals, which do not fulfill the NIH diagnostic criteria, most often in young children, if it can affect clinical management.

The presence of only pigmented lesions at early age is a diagnostic dilemma between NF1 and LEGIUS (caused by SPRED1 gene mutations). The distinction between NF1 and LEGIUS in young children, in the absence of NF1 family history and neoplastic or osseous manifestations can only be achieved by genetic testing. It is cost saving and easier to start by investigation of SPRED1 gene than by NF1, because SPREAD1 contains only 8 exons $^{7}$.

It is important to emphasize that currently there are only two important genotypes that correlate to phenotype in NF1. One of these is the microdeletion syndrome, in which a large part of or the whole NF1 gene is absent and is associated with a more severe phenotype ${ }^{25}$. The other genotype is the mutation involving the deletion of three base pairs in exon 17, which correlates with a mild phenotype ${ }^{26}$. Therefore, discarding these two specific genotypes, it is not possible to predict the severity of the disease based on NF1 genetic testing.

\section{NF2}

It is expected that $25 \%$ to $33 \%$ of those who have NF2 and are a single occurrence in the family (simplex cases) are mosaic for NF2 mutation. The mutation detection rate by sequencing and deletion/duplication analysis is around $92 \%$ for familial cases and $72 \%$ in simplex cases. NF2 genetic testing may be helpful in specific cases and, although some genotype-phenotype correlations in NF2 are known, it cannot yet predict the severity of the disease ${ }^{27}$.

\section{a. Pre-symptomatic testing of at-risk patients}

Because detection of tumors at an early stage is effective in improving the clinical management of NF2 patients, the screening for NF2 in children of affected patients can start 
Table 5. Differential diagnosis in neurofibromatosis (NF).

\begin{tabular}{|c|c|c|}
\hline Group & & Main characteristics \\
\hline \multirow[t]{8}{*}{ Other CAL conditions } & Isolated CAL & $10 \%$ of general population (one or two CAL) \\
\hline & Familial CAL & Isolated CAL, autosomal dominant. \\
\hline & Legius Syndrome & $\begin{array}{l}\text { Multiple CAL, freckling, cognitive deficits and macrocephaly, autosomal dominant. } \\
\text { Without Lisch nodules, neurofibromas or CNS tumors }\end{array}$ \\
\hline & $\begin{array}{l}\text { DNA Repair Deficiency } \\
\text { Syndrome }\end{array}$ & $\begin{array}{c}\text { CAL, tumors, hematological malignant diseases, hereditary colon cancer without } \\
\text { multiple polyposes, autosomal recessive. }\end{array}$ \\
\hline & NF1-Noonan Syndrome & $\begin{array}{c}\text { CAL, ocular hypertelorism, down-slanting palpebral fissures, low-set ears, webbed } \\
\text { neck, short stature, and congenital heart disease. } 12 \% \text { of individuals with NF1, } \\
\text { autosomal dominant. }\end{array}$ \\
\hline & Piebaldism & $\begin{array}{c}\text { Areas of cutaneous pigmentation and depigmentation, white forelock; autosomal } \\
\text { dominant. }\end{array}$ \\
\hline & Bloom Syndrome & $\begin{array}{l}\text { Erythematous and sun-sensitive skin lesion of the face; severe pre- and postnatal } \\
\text { growth deficiency; autosomal recessive. }\end{array}$ \\
\hline & Fanconi Anemia & $\begin{array}{c}\text { CAL or skin hypopigmentation; short stature; malformations of the thumbs, forearms; } \\
\text { progressive bone marrow failure; autosomal recessive. }\end{array}$ \\
\hline \multirow[t]{5}{*}{$\begin{array}{l}\text { Skin disorders with CNS } \\
\text { tumors }\end{array}$} & Tuberous Sclerosis Complex & $\begin{array}{c}\text { Hypomelanotic skin macules, facial angiofibromas, shagreen patches, fibrous facial } \\
\text { plaques, ungueal fibromas, SNC tumors, seizures, cognitive deficits, behavioral } \\
\text { disorders; autosomal dominant. }\end{array}$ \\
\hline & McCune-Albright Syndrome & CAL, polyostotic fibrous dysplasia, precocious puberty; sporadic. \\
\hline & Ataxia-telangiectasia & $\begin{array}{l}\text { Slurred speech, truncal ataxia, and oculomotor apraxia beginning between ages one } \\
\text { and four years, telangiectasias of the conjunctivae, low immunity; autosomal recessive. }\end{array}$ \\
\hline & $\begin{array}{l}\text { Gorlin Syndrome (nevoid } \\
\text { basal cell carcinoma } \\
\text { syndrome) }\end{array}$ & $\begin{array}{l}\text { Risk of developing cancerous and noncancerous tumors, most often basal cell } \\
\text { carcinoma, less often meduloblastoma during childhood; autosomal dominant. }\end{array}$ \\
\hline & $\begin{array}{l}\text { Sturge-Weber syndrome } \\
\text { (encephalotrigeminal } \\
\text { angiomatosis) }\end{array}$ & $\begin{array}{l}\text { Congenital facial cutaneous port-wine stain with associated CNS (developmental delay, } \\
\text { seizures) and ocular abnormalities (buphtalmos, eye hemangiomas); unclear etiology. }\end{array}$ \\
\hline \multirow[t]{3}{*}{$\begin{array}{l}\text { Maculae conditions } \\
\text { misdiagnosed with CAL }\end{array}$} & LEOPARD Syndrome & $\begin{array}{c}\text { Multiple lentigines, hypertelorism, sensorineural deafness, hypertrophic } \\
\text { cardiomyopathy; autosomal dominant. }\end{array}$ \\
\hline & Neurocutaneous melanosis & $\begin{array}{c}\text { Large or multiple congenital melanocytic nevi and benign or malignant pigment cell } \\
\text { tumors of the leptomeninges; sporadic. }\end{array}$ \\
\hline & Peutz-Jeghers Syndrome & $\begin{array}{l}\text { Gastrointestinal polyposis, mucocutaneous pigmentation, and cancer predisposition; } \\
\text { autosomal dominant. }\end{array}$ \\
\hline \multirow[t]{2}{*}{$\begin{array}{l}\text { Locally excessive } \\
\text { growing syndromes }\end{array}$} & $\begin{array}{l}\text { Klippel-Trenauney-Weber } \\
\text { Syndrome }\end{array}$ & $\begin{array}{l}\text { Large cutaneous hemangiomata with hypertrophy of the related bones and soft } \\
\text { tissues; sporadic. }\end{array}$ \\
\hline & Proteus Syndrome & $\begin{array}{l}\text { Progressive, segmental or patchy postnatal overgrowth of diverse tissues (skeleton, } \\
\text { skin, adipose and SNC), linear verrucous epidermal nevus; sporadic. }\end{array}$ \\
\hline \multirow{4}{*}{$\begin{array}{l}\text { Tumor conditions } \\
\text { misdiagnosed with } \\
\text { neurofibromas }\end{array}$} & Lipomatosis & Trunk and limb multiple lipomas; autosomal dominant. \\
\hline & $\begin{array}{l}\text { Banayan-Riley-Ruvalcaba } \\
\text { Syndrome }\end{array}$ & $\begin{array}{c}\text { Multiple lipomas and hemangiomas, macrocephaly, pigmented macules of the glan } \\
\text { penis, cognitive deficit; autosomal dominant. }\end{array}$ \\
\hline & $\begin{array}{l}\text { Congenital generalized } \\
\text { fibromatosis }\end{array}$ & $\begin{array}{l}\text { Multiple nodules of fibrous tissue, congenital or apparent before age of } 2 \text { years, in muscle, } \\
\text { bone, subcutaneous tissue and viscera, fatal or undergoing spontaneous remission. }\end{array}$ \\
\hline & $\begin{array}{l}\text { Endrocrine multiple neoplasias } \\
\text { type 2B (MEN2B) }\end{array}$ & $\begin{array}{c}\text { Medullary thyroid carcinoma, pheochromocytomas, mucosal neuromas, } \\
\text { sometimes CAL; autosomal dominant. }\end{array}$ \\
\hline
\end{tabular}

CAL: cafe au lait patches; CNS: central nervous system. 
Table 6. Transmission risk of neurofibromatosis (NF2) to offspring for isolated cases of Neurofibromatosis type 2 before and after blood genetic test. Adapted from Evans and Wallace, $2008^{29}$.

\begin{tabular}{lcc}
\hline $\begin{array}{l}\text { Age of diagnosis } \\
\text { of vestibular } \\
\text { schwannoma }\end{array}$ & $\begin{array}{c}\text { Transmission risk } \\
\text { pre blood genetic } \\
\text { test }\end{array}$ & $\begin{array}{c}\text { Transmission risk } \\
\text { post negative blood } \\
\text { testing }\end{array}$ \\
\hline$<20$ BVS & $45 \%$ & $29 \%$ \\
$<20$ UVS & $33 \%$ & $15 \%$ \\
$20-29$ BVS & $36 \%$ & $15 \%$ \\
$20-29$ UVS & $19 \%$ & $6 \%$ \\
$30-39$ BVS & $28 \%$ & $11 \%$ \\
$30-39$ UVS & $12 \%$ & $6 \%$ \\
$40+$ BVS & $22 \%$ & $9 \%$ \\
$40+$ UVS & $10 \%$ & $5.5 \%$ \\
\hline
\end{tabular}

BVS: bilateral vestibular schwannoma; UVS: unilateral vestibular schwannoma.

at birth with the search of cataracts ${ }^{28}$. If no cataracts are found, pre-symptomatic genetic testing, if possible, should be considered.

\section{b. Determining the diagnosis of patients who fall short of the Manchester criteria, including mosaic patients}

In cases of patients that fall short of the Manchester criteria, genetic testing may be helpful in establishing the diagnosis. The diagnosis of NF2 is usually a challenge when mosaicism is present. Mutations with mosaicism levels greater than $10 \%$ can be detected in blood DNA, otherwise its identification requires testing of tumor material. In these cases, the diagnosis is established if two NF2 identical mutations are found in separate tumors, but is not present in blood ${ }^{26}$.

\section{c. Estimating the transmission risk for mosaic patients}

The transmission rate of NF2 is 50\% in the second generation, but the risk of transmission in apparently isolated patients with NF2 is less than $50 \%$ due to mosaicism. Transmission risk of NF2 decreases significantly after the proband has had negative genetic testing using a blood sample (Table 6) ${ }^{27}$.

\section{SCHWANNOMATOSIS (SCH)}

Currently, it is known that germline mutations in SMARCB1 (or INI1) gene are associated to $\mathrm{SCH}$. Nevertheless, they are found in only $40-50 \%$ of the familial cases and in $8-10 \%$ of the sporadic cases of SCH. For SCH cases unrelated to SMARCB1 germline mutations, the genetic alterations are not known ${ }^{27}$.

SMARCB1 gene testing may be ordered for individuals with multiple schwannomas without evidence of vestibular tumor and no NF2 mutation detected in the blood. Nevertheless, there is a great chance of not detecting a $S M A R C B 1$ genetic alteration and the diagnosis of SCH cannot be ruled out. $S M A R C B 1$ gene testing is also indicated for early detection of at-risk patients (because of family history) for management reasons.

Tumorigenesis of schwannomas associated to $\mathrm{SCH}$ is believed to occur through a four-hit model, involving not only mutations in SMARCB1 alleles (hits 1 and 2), but also

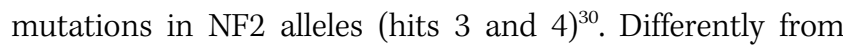
NF2-associated schwannomas, SCH-associated schwannomas of the same individual usually carry different somatic NF2 mutations. Therefore, mutational analysis of schwannoma cells is also highly relevant for the diagnosis, even in the absence of $S M A R C B 1$ mutation in blood. The finding of different NF2 somatic mutations in different schwannomas of the same individual, although not indicative of the presence of a germline $S M A R C B 1$, at least rules out the diagnosis of NF2 mosaicism ${ }^{31}$.

\section{GENETIC TESTING FOR PREIMPLANTATION GENETIC DIAGNOSIS (PGD) OF NF}

Another application of NF genetic test is for the PGD. It comprises a set of procedures to test a specific genetic alteration and selecting unaffected embryos for transfer to the uterus. It is a highly specialized method performed in a few centers and is available for couples when the parental mutation has already been identified. It has been shown as a promising and useful method, being the only one that prevents transmission of the mutated gene from one parent to their children ${ }^{32}$. For an updated list of centers that perform PGD for NF, please refer to www.genetests.org

\section{References}

1. Riccardi VM. Historical background and introduction. In: Friedman JM, Gutmann DH, MacCollin M, Riccardi VM (Eds). Neurofibromatosis - Phenotype, Natural History, and Pathogenesis. 3 ed. Baltimore: The Johns Hopkins University Press, 1999:1-28.
2. Geller M, Bonalumi Filho A. Neurofibromatose: clínica, genética e terapêutica. 1 ed. Rio de Janeiro: Guanabara Koogan, 2004.

3. Huson SM. The neurofibromatoses: differential diagnosis and rare subtypes. In: Ferner RE, Huson SM, Evans DG (Eds). 
Neurofibromatoses in Clinical Practice. 1 ed. London: Springer-Verlag London Limited, 2011:1-46.

4. Ferner RE. Neurofibromatosis 1. In: Ferner RE, Huson SM, Evans DG (Eds.) Neurofibromatoses in clinical practice. 1 ed. London: SpringerVerlag London Limited, 2011:1-46.

5. Boyd KP, Gao L, Feng R, et al. Phenotypic variability among cafe-aulait macules in neurofibromatosis type 1. J Am Acad Dermatol 2010;63:440-447.

6. Nunley KS, Gao F, Albers AC, Bayliss SJ, Gutmann DH. Predictive value of cafe au lait macules at initial consultation in the diagnosis of neurofibromatosis type 1. Arch Dermatol 2009;145:883-887.

7. Brems H, Pasmant E, Van Minkelen R, et al. Review and update of SPRED1 mutations causing Legius syndrome. Hum Mutat 2012;33:1538-1546.

8. National Institutes of Health Consensus Development Conference Statement: neurofibromatosis. Bethesda, Md., USA, July 13-15, 1987. Neurofibromatosis 1988;1:172-178.

9. Trovo-Marqui AB, Goloni-Bertollo EM, et al. High frequencies of plexiform neurofibromas, mental retardation, learning difficulties, and scoliosis in Brazilian patients with neurofibromatosis type 1. Braz J Med Biol Res 2005;38:1441-1447

10. Darrigo Jr LG, Geller M, Bonalumi Filho A, Azulay DR. Prevalence of plexiform neurofibroma in children and adolescents with type I neurofibromatosis. J Pediatr (Rio J) 2007;83:571-573.

11. Souza JFd, Toledo LLd, Ferreira MCM, Rodrigues LOC, Rezende NAd. Neurofibromatose tipo 1: mais comum e grave do que se imagina. Rev Assoc Méd Bras 2009;55:394-399.

12. Lin AL, Gutmann DH. Advances in the treatment of neurofibromatosis-associated tumours. Nat Rev Clin Oncol 2013;10:616-624.

13. DeBella K, Poskitt K, Szudek J, Friedman JM. Use of "unidentified bright objects" on MRI for diagnosis of neurofibromatosis 1 in children. Neurology 2000;54:1646-1651.

14. Huson SM, Harper PS, Compston DA. Von Recklinghausen neurofibromatosis. A clinical and population study in south-east Wales. Brain 1988;111:1355-1381.

15. Ferner RE, Huson SM, Thomas N, et al. Guidelines for the diagnosis and management of individuals with neurofibromatosis 1. J Med Genet 2007;44:81-88.

16. Cunha KS, Geller M. Advances in neurofibromatosis research. 1 ed. New York, USA: Nova Science Publishers Inc, 2012:1-273.

17. Carranza AC, Salinas Martín MV, Polo R, Córdoba JC, GonzálezCámpora R. Problemas diagnósticos en tumores del nervio periférico (I and II). Rev Esp Patol 2011:97-116.

18. Park SJ, Sawitzki B, Kluwe L, Mautner VF, Holtkamp N, Kurtz A. Serum biomarkers for neurofibromatosis type 1 and early detection of malignant peripheral nerve-sheath tumors. BMC Med 2013;11:109.
19. HO Classification of Tumours of the central nervous system. 4 ed: WHO; 2007:1-312.

20. Blakeley JO, Evans DG, Adler J, et al. Consensus recommendations for current treatments and accelerating clinical trials for patients with neurofibromatosis type 2. Am J Med Genet A 2012:158:24-41.

21. MacCollin M. Neurofibromatosis 2: clinical aspects. In: Friedman JM, Gutmann DH, MacCollin M, Riccardi VM (Eds). Neurofibromatosis - phenotype, natural history, and pathogenesis. 3 ed. Baltimore: The Johns Hopkins University Press, 1999:299-326.

22. Baser ME, Friedman JM, Wallace AJ, Ramsden RT, Joe H, Evans DG. Evaluation of clinical diagnostic criteria for neurofibromatosis 2. Neurology 2002;59:1759-1765.

23. MacCollin M, Chiocca EA, Evans DG, et al. Diagnostic criteria for schwannomatosis. Neurology 2005;64:1838-1845.

24. Friedman JM. Neurofibromatosis 1. Seattle (WA): University of Washington, Seattle; 1993-2013; 1998 (Updated 2012) [cited 2013]. Available from: http://www.ncbi.nlm.nih.gov/books/NBK1109/.

25. Pasmant E, Sabbagh A, Spurlock G, et al. NF1 microdeletions in neurofibromatosis type 1: from genotype to phenotype. Hum Mutat 2010;31:1506-1518.

26. Upadhyaya M, Huson SM, Davies M, et al. An absence of cutaneous neurofibromas associated with a 3-bp inframe deletion in exon 17 of the NF1 gene (c.2970-2972 delAAT): evidence of a clinically significant NF1 genotype-phenotype correlation. Am J Hum Genet 2007;80:140-151.

27. Nunes F. Research advances in mutational analysis of the NF2 gene. In: Cunha K, Geller M, editors. Advances in neurofibromatosis research. 1 ed. New York, USA: Nova Science Publishers Inc, 2012:165-80.

28. Evans DG, Raymond FL, Barwell JG, Halliday D. Genetic testing and screening of individuals at risk of NF2. Clin Genet 2012;82:416-424.

29. Evans DG, Wallace A. An update on age related mosaic and offspring risk in neurofibromatosis 2 (NF2). J Med Genet 2009;46:792-800.

30. Plotkin SR, Blakeley JO, Evans DG, et al. Update from the 2011 International Schwannomatosis Workshop: From genetics to diagnostic criteria. Am J Med Genet A 2013;161:405-416.

31. Papi L. Schwannomatosis: a recently recognized form of neurofibromatosis. In: Cunha K, Geller M (Eds). Advances in Neurofibromatosis Research. 1 ed. New York, USA: Nova Science Publishers Inc, 2012:258-267.

32. Bonalumi Filho A, Darrigo Jr L, Oliveira L, Azulay D, Cunha K. Preimplantation genetic diagnosis of neurofibromatosis. In: Cunha K, Geller M (Eds). Advances in Neurofibromatosis Research. 1 ed. New York, USA: Nova Science Publishers Inc, 2012:258-267. 